\title{
Boiling pure fluids at sub atmospheric pressures
}

\author{
Touhami BAKI ${ }^{1}$ \\ ${ }^{1}$ Faculty of Mechanics, \\ Gaseous Fuels and Environment \\ Laboratory, \\ USTO-MB, BP 1505, El-M'Naouer, \\ Oran 31000, Algeria. \\ E-mail: touhami.baki@univ-usto.dz
}

\begin{abstract}
The study and sizing of sorption machine evaporators are based on the prediction of the heat transfer coefficient at atmospheric pressures, but in the literature we only find correlations modeled from experiments for a wide range of pressure, where the majority of the data are above atmospheric pressure; A review of the experiments of boiling at sub-atmospheric pressures was carried out and compared to four known correlations for three types of fluids, which are water, hydrocarbons and refrigerants; The results obtained showed deviations of the predicted data from the experimental values for three correlations and convincing results for the fourth.
\end{abstract}

Keywords- boiling, correlation, heat transfer coefficient, pressure, sub-atmospheric.

\section{INTRODUCTION (HEADING 1)}

The heat transfer during pool boiling is used in refrigeration evaporators, air conditioning heat pumps and industrial processes, it is sought after for its heat transfer efficiency for low temperature gradients, on the other hand it is very sensitive to parametric effects.

The needs for cooling and air conditioning are growing, this demand is met by steam compression machines, which are very widespread in the industrial and domestic fields; another type of machine, sorption refrigeration machines have appeared and are increasingly developed, their advantages are that they meet new directives and regulations for the protection of the environment.

The design and manufacture of two-phase equipment, such as the evaporator requires a better knowledge of the phenomenon of boiling at sub-atmospheric pressures ; the modeling of correlations during the pool boiling is relatively well studied, but at low pressures new phenomena appear and the valid correlations for the pool boiling should be checked or readjusted.

Low pressure boiling shows totally different characteristics to known boiling regimes such as nucleate or film boiling as pointed out by Florence Giraud et al [1] ; where they detected a new boiling regime, which is characterized by high growth rates, longer waiting times and larges volumes of bubbles at detachment, in addition they observed the non-homogeneity of the pressure and the saturation temperature.

Baki and Aris [2] made the experimental study of the boiling of R141b on a horizontal tube, the results were compared with three known correlations, Baki et al [3] and Touhami et al [4] studied the impact of the outer diameter of a horizontal tube during pool boiling and have proposed a correlation that can give the coefficient of heat transfer as a function of the diameter and the thermo-physical characteristics of the fluid, Baki [5-7] compared experimental data of the boiling of fluids outside a horizontal tube with known correlations, Baki [8] studied pool boiling and its limits of hydrogen and compared many correlations with experimental data, also analyzed the onset and the critical heat flux.

The objective of this article is to compare the experimental data collected of the heat transfer coefficient from the literature with values predicted by four known correlations of pool boiling at sub-atmospheric pressures, for several pure fluids.

\section{REVIEW OF CORRELATIONS AND EXPERIMENTAL DATA}

From the literature we have drawn four correlations from known authors $[9,12]$, these relationships have been modeled from experimental data and being able to predict the heat transfer coefficient during pool boiling, they are drawn up in the table 1 .

All of these correlations from (1) to (4) make it possible to calculate the heat transfer coefficient directly, or indirectly through the heat flux; the predicted values are determined as a function of the heat flux, the thermo-physical characteristics of the fluid and the pressure.

Kruzhlin's correlation (1) [9] calculates the heat transfer coefficient as a function of the heat flux and the characteristics of the fluid; The correlation (2) of Mc Nelly [10] determines the heat transfer coefficient from the heat flux of the density ratio of some thermo-physical parameters and the operating pressure; Mostinski's correlation (3) [11] gives the heat transfer coefficient as a function of critical pressure, heat flux and a function of reduced pressure; Labuntsov's correlation (4) [12] determines the heat transfer coefficient as a function of thermo-physical parameters, saturation temperature and heat flux.

Table 2 groups together the experimental data from the literature $[13,24]$, which relate to the pool boiling of pure fluids at sub-atmospheric pressures, totaling 548 points. In this case, the heating element is tube or disc, the absolute pressure varies from 0.3 to $100 \mathrm{kN} / \mathrm{m}^{2}$; The heat flux covers a range of 0.1 to $446 \mathrm{~kW} / \mathrm{m}^{2}$, the heat transfer coefficient is between 0.2 and $18.6 \mathrm{~kW} / \mathrm{m}^{2} . \mathrm{K}$; grades are stainless steel, brass and copper, the substances used are water, hydrocarbons and refrigerants, the thermo-physical parameters of fluids at saturation are draw from the NIST site ( National Institute of Standard and Technology).

Figure 1 shows the relationship between the heat flux and the heat transfer coefficient for all the data points collected from the experiments $[13,24]$, the set of plotted points follows a curve trend except for a group of points of the series [22] which deviate from the whole. 
Table 1: Boiling Correlation.

\begin{tabular}{|c|lr|}
\hline Author, Reference / Year & \multicolumn{3}{|c|}{ Correlation } \\
\hline Kruzhilin, [9] / 1947 & $\frac{h l_{c}}{\lambda}=0.082\left(\frac{L q}{g\left(T_{S a t}+273.15\right) \lambda} \frac{\rho_{v}}{\rho_{l}-\rho_{v}}\right)^{0.7}\left(\frac{\left(T_{s a t}+273.15\right) c_{p} \sigma \rho_{l}}{L^{2} \rho_{v} l_{c}}\right)^{0.33} \operatorname{Pr}^{-0.45}$ & $(1)$ \\
\hline Mc Nelly, [10] / 1953 & $h=0.225\left(\frac{q c_{p}}{L}\right)^{0.69}\left(\frac{P \lambda}{\sigma}\right)^{0.31}\left(\frac{\rho_{l}}{\rho_{v}}-1\right)^{0.32}$ & $(2)$ \\
\hline Mostinski, [11] / 1963 & $h=0.106 P_{c r}^{0.69} q^{2 / 3} F_{p}$ and $F_{p}=1.8\left(p_{r}\right)^{0.17}+4\left(p_{r}\right)^{1.2}+10\left(p_{r}\right)^{10}$ & $(3)$ \\
\hline Labuntsov, [12] / 1972 & $h=0.075\left[1+10\left(\frac{\rho_{v}}{\rho_{l}-\rho_{v}}\right)^{0.67}\right]\left(\frac{\lambda^{2}}{v \sigma T_{s a t}}\right)^{0.33} q^{0.67}$ \\
\hline
\end{tabular}

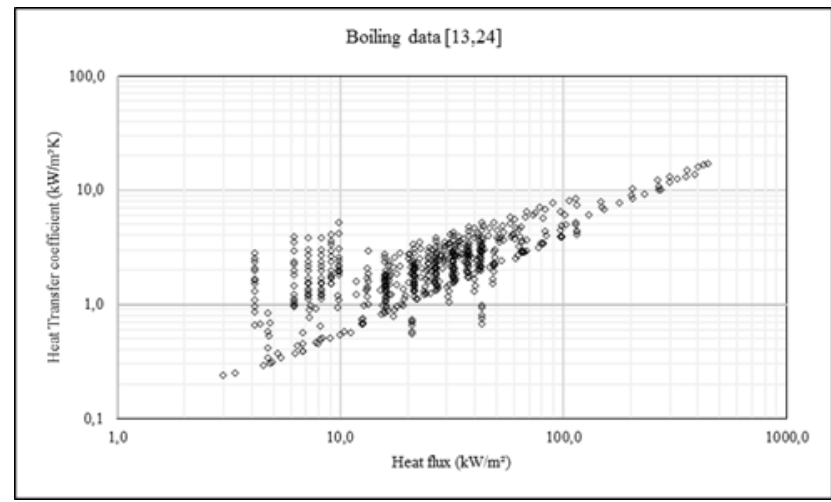

Figure 1- Experimental data of boiling

\section{COMPARISON FO CORRELATIONS}

The comparison of the values predicted by the correlations with the experimental data, is treated statistically by defining the error by equation (5), the mean error (6) and the correlation coefficient (7), the latter measuring the affinity between the two groups of values, the more the coefficient tends towards the unit value and the more the values calculated with the corresponding correlation approach the experimental values and give low mean errors.

$$
\begin{aligned}
& \text { Error }=\left|\frac{h_{\text {cal }}-h_{\text {exp }}}{h_{\text {cal }}}\right| \\
& \text { Mean Error }=\sum_{i=1}^{n} \frac{\text { Erreur }_{i}}{n} \\
& r=\frac{\text { covariance }_{h_{\text {exp } h_{c a l}}}}{\text { variance }_{h_{\text {exp }} . \text { variance }_{h_{\text {cal }}}}}
\end{aligned}
$$

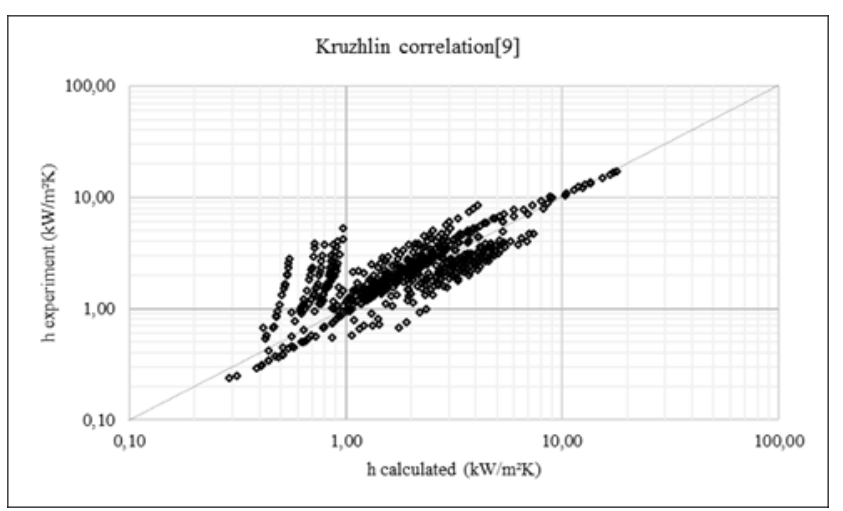

Figure 2. Comparison of data with correlation [9]

\section{Kruzhlin correlation [9]}

Figure 2 shows the comparison of the experimental data to that calculated with the Kruzhlin correlation [9], the points are mostly near the median line, except for the series of data
[22] which are increased to the experimental ones, the mean error is $48 \%$ and the correlation coefficient is 0.90 .

\section{Mc Nelly correlation [10]}

Figure 3 indicates that the points obtained are mostly below the median line, the Mc Nelly correlation [10] underestimates the predicted values to those of the experimental values, a series of data relating to water [22] is above the set, the error mean is $40 \%$ and the correlation coefficient is 0.91 .

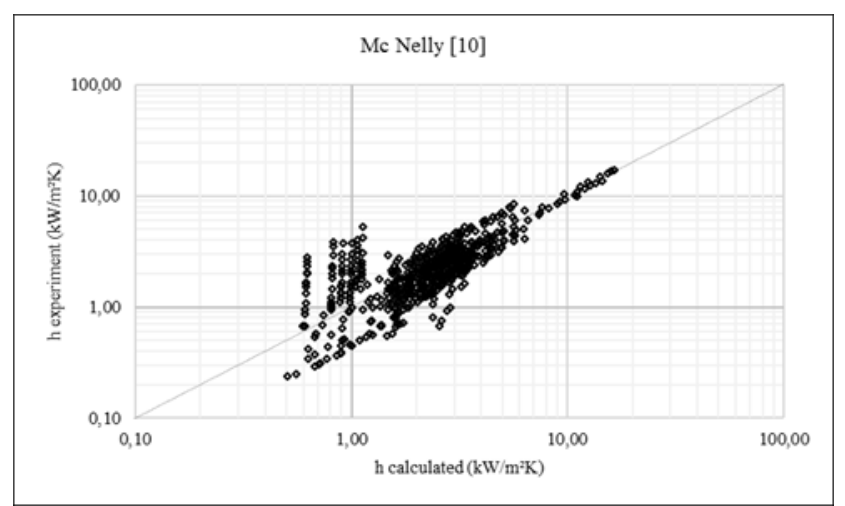

Figure 3. Comparison of data with the correlation [10]

\section{Mostinski correlation [11]}

Figure 4 shows a comparison of the heat transfer coefficients of the experimental data with those calculated with Mostinski's correlation [11], one set of points are concentrated above the midline another group of points is below, the average error is of the order of $73 \%$ and the correlation coefficient which indicates the affinity of the two types of values is determined and is equal to 0.90 .

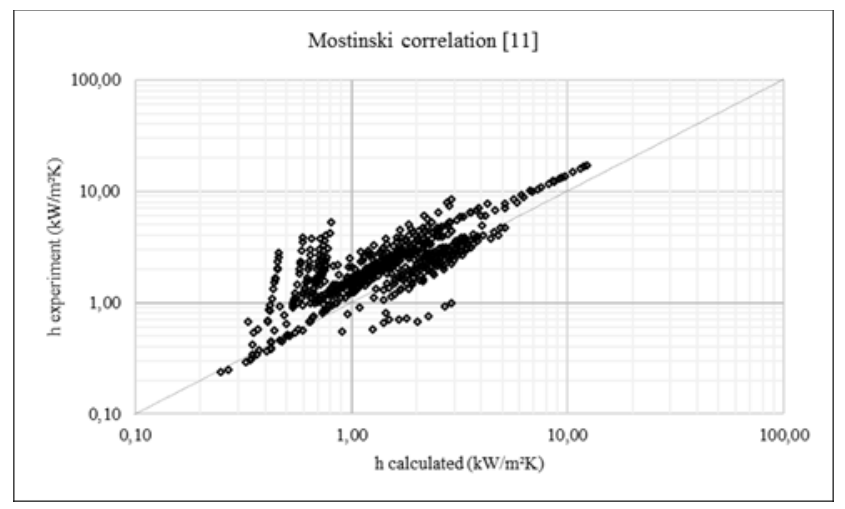

Figure 4. Comparison of data with correlation [11] 
INTERNATIONAL JOURNAL OF MATHEMATICS AND COMPUTERS IN SIMULATION

Table 2: experimental data of boiling at sub-atmospheric pressures

\begin{tabular}{|c|c|c|c|c|c|c|c|}
\hline Reference & Fluid & Heater $(\mathrm{mm})$ & Roughness & Flux kW/m² & $\mathrm{h} \mathrm{kW} / \mathrm{m}^{2} . \mathrm{K}$ & $\mathrm{P}$ & Nr Points \\
\hline $\begin{array}{c}\text { [13] P.K. TEWARI, et al / } \\
1985\end{array}$ & Water & $\begin{array}{l}\text { Plate } \mathrm{d}=150, \mathrm{e}=3 ; \\
\text { Copper }\end{array}$ & $\begin{array}{c}\mathrm{Ra}=0.2-0.3 \mu \mathrm{m} \\
\mathrm{Ra}=4-10 \mu \mathrm{m} \\
\mathrm{Ra}=10-20 \mu \mathrm{m}\end{array}$ & $15,1-68,4$ & $1,3-4,7$ & $10-100 \mathrm{kPa}$ & $\begin{array}{l}19 \\
11 \\
21\end{array}$ \\
\hline [14] Varma et al / 1994 & Water & Tube Ss $/ \mathrm{d}=14,05 / \mathrm{L}=240$ & ND & $25-83$ & $3-7$ & $6,67 \mathrm{kN} / \mathrm{m}^{2}$ & 10 \\
\hline [15] Bhaumik et al / 2004 & $\begin{array}{c}\text { Water } \\
\text { Benzène } \\
\text { Toluène } \\
\end{array}$ & Tube Ss $/ \mathrm{d}=32 / \mathrm{L}=150$ & ND & $\begin{array}{l}16-42 \\
16-43 \\
16-43 \\
\end{array}$ & $\begin{array}{c}1,1-3,5 \\
1-2,9 \\
1-1,5 \\
\end{array}$ & $\begin{array}{l}20,01-97,39 \mathrm{kN} / \mathrm{m}^{2} \\
23,75-97,13 \mathrm{kN} / \mathrm{m}^{2} \\
23,35-96,72 \mathrm{kN} / \mathrm{m}^{2}\end{array}$ & $\begin{array}{l}36 \\
36 \\
36 \\
\end{array}$ \\
\hline [16] Jabardo et al / 2004 & $\begin{array}{l}\text { R-11, } \\
\text { R-123 }\end{array}$ & $\begin{array}{l}\text { Tube Copper } \\
\mathrm{d}=19 / \mathrm{L}=210\end{array}$ & $\begin{array}{l}\mathrm{Ra}=0,16-2,3 \mu \mathrm{m} \\
\mathrm{Ra}=0,16-3,3 \mu \mathrm{m}\end{array}$ & $\begin{array}{l}5-115 \\
5-115 \\
\end{array}$ & $\begin{array}{l}0,3-8,5 \\
0,3-7,4\end{array}$ & $\begin{array}{l}0,485 \text { bar } \\
0,403 \text { bar }\end{array}$ & $\begin{array}{l}50 \\
45\end{array}$ \\
\hline [17] Prasad et / 2007 & Méthanol & $\begin{array}{l}\text { Tube Mild steel, copper } \\
\text { coated } d=32 / L=145\end{array}$ & ND & $\begin{array}{l}15-43 \\
15-43\end{array}$ & $\begin{array}{l}1,4-3,8 \\
1,7-5,2\end{array}$ & $\begin{array}{l}27,95-97,23 \mathrm{kN} / \mathrm{m}^{2} \\
27,72-97,56 \mathrm{kN} / \mathrm{m}^{2}\end{array}$ & $\begin{array}{l}30 \\
30\end{array}$ \\
\hline $\begin{array}{l}\text { [18] Lena Schnabel et al } \\
\text { /2008 }\end{array}$ & Water & $\begin{array}{c}\text { Cylinder Copper } \mathrm{d}=38, \\
\mathrm{e}=4,5\end{array}$ & $\begin{array}{c}\mathrm{Ra}=0.169 \mu \mathrm{m} \\
\mathrm{Ra}=5.8 \mu \mathrm{m}\end{array}$ & $1,7-4,9$ & $0,7-2,2$ & $1-2 \mathrm{kPa}$ & $\begin{array}{l}6 \\
9\end{array}$ \\
\hline [19] Saiz Jabardo / 2009 & R-123 & $\begin{array}{c}\text { Tube Brass Copper } \\
\mathrm{d}=19 / \mathrm{L}=210 \\
\end{array}$ & $\begin{array}{l}\mathrm{Ra}=0,16 \mu \mathrm{m} \\
\mathrm{Ra}=0,16 \mu \mathrm{m}\end{array}$ & $\begin{array}{c}3-77 \\
3-115 \\
\end{array}$ & $\begin{array}{l}0,2-3,2 \\
0,3-4,1 \\
\end{array}$ & $\begin{array}{l}0,403 \text { bar } \\
0,403 \text { bar }\end{array}$ & $\begin{array}{l}17 \\
17 \\
\end{array}$ \\
\hline $\begin{array}{l}\text { [20] Mark Aaron Chan et al } \\
\qquad / 2010\end{array}$ & Water & Disc $d=30 / t=27$ & ND & $0,1-446$ & $6-17$ & $2-9 \mathrm{kPa}$ & 24 \\
\hline [21] Cieśliński et al / 2011 & Water & Tube Ss $10 / 100$ & $\mathrm{Ra}=0,06 \mu \mathrm{m}$ & $13-90$ & $2,9-7,7$ & $10 \mathrm{kPa}$ & 9 \\
\hline [22] Yu et al /2015 & Water & $\begin{array}{c}\begin{array}{c}\text { Tube Copper } \\
\mathrm{d}=20,8 / \mathrm{L}=190\end{array} \\
\end{array}$ & ND & $4-10$ & $0,7-5,3$ & $1,8-3,5 \mathrm{kPa}$ & 77 \\
\hline $\begin{array}{c}\text { [23] Tomasz HAŁON et al } \\
\text { / } 2015\end{array}$ & Methanol & Brass circular plate $\mathrm{d}=77$ & $\mathrm{Ra}=0.05 \mathrm{~mm}$ & $21-43$ & $0,3-18,6$ & $0.3-18 \mathrm{kPa}$ & 11 \\
\hline [24] Kumar et al /2019 & $\begin{array}{c}\text { Water } \\
\text { Benzene }\end{array}$ & Tube Ss $d=70, L=179$ & ND & $\begin{array}{c}13-34 \\
5-25\end{array}$ & $\begin{array}{l}1,4-3,9 \\
0,5-2,5 \\
\end{array}$ & $\begin{array}{c}35,36-100,07 \mathrm{kN} / \mathrm{m}^{2} \\
39,29-98,07 \mathrm{kN} / \mathrm{m}^{2}\end{array}$ & $\begin{array}{l}29 \\
25 \\
\end{array}$ \\
\hline
\end{tabular}




\section{Labuntsov correlation [12]}

Labuntsov's correlation [12] gives results with an error of around $55 \%$ and a correlation coefficient of 0.91 , two sets of points stand out, one group around the median line and another above and on the right, see figure 5.

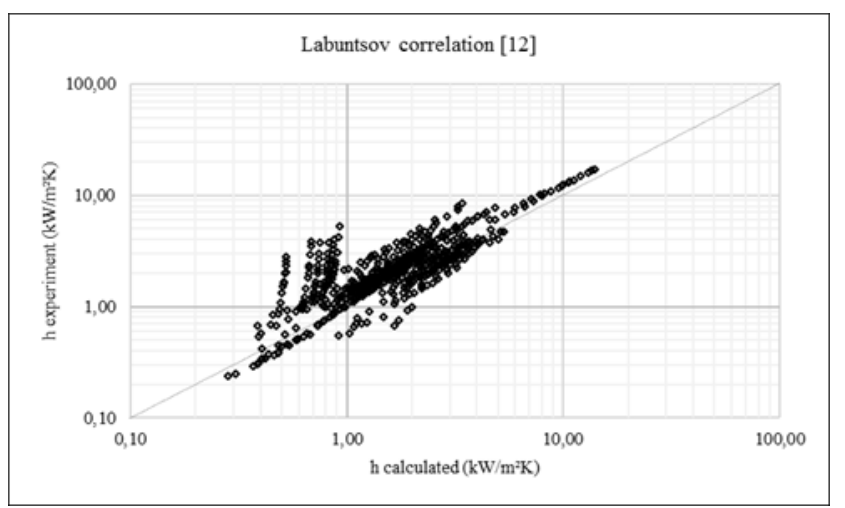

Figure 5. Comparison of data with correlation [12]

\section{CONCLUSION}

- Correlations predicting the heat transfer coefficient were drawn from the literature and a review of the experimental data relating to boiling for subatmospheric pressures was made.

- An analysis of the experimental data was carried out showing the variability of several parameters influencing the boiling.

- The validation of the correlations with the experimental data gave results with margins of error of 40 to $73 \%$.

- Of the four correlations treated, that of Mc Nelly [10] gave the best results with a minimum of error and a high correlation coefficient.

\section{NOMENCLATURE}

\section{NOMENCLATURE}

$a$ Thermal diffusivity $\left(\mathrm{m}^{2} / \mathrm{s}\right)$

$c_{p} \quad$ Heat capacity $(\mathrm{J} / \mathrm{kg} . \mathrm{K})$

$F_{p} \quad$ Pressure function [10]

$g$ Gravity acceleration $\left(\mathrm{m} / \mathrm{s}^{2}\right)$

$h$ Heat transfer Coefficient $\left(W / m^{2} . K\right)$

$l_{c} \quad$ Capillary length $(m)$

$L \quad$ Latent heat of vaporization $(J / k g)$

$\mathrm{Nu}$ Nusselt Number

$P$ Pressure $\left(\mathrm{N} / \mathrm{m}^{2}\right)$

$\operatorname{Pr}$ Prandtl Number

$q$ Heat flux $\left(W / m^{2}\right)$

$r$ Correlation coefficient

$R_{a}$ Arithmetic roughness ( $\mathrm{nm}$ )

Re Reynolds Number

$T$ Temperature $(K)$

\section{Greek symbols}

$\beta \quad$ Angle contact (degree)

$\Delta$ Difference

$\varepsilon \quad$ Quadratic roughness $(\mu \mathrm{m})$

$\lambda$ Thermal conductivity $(W / m . K)$ $\mu \quad$ Dynamic viscosity (Pa.s)

$v \quad$ Kinematic viscosity $\left(\mathrm{m}^{2} / \mathrm{s}\right)$

$\rho$ Density $\left(K g / \mathrm{m}^{3}\right)$

$\sigma$ Surface tension $(N / m)$

Subscripts

c Critic

cal Calculated

d Departure

exp experimental

$l \quad$ Liquid

$v \quad$ Vapor

$w \quad$ Wall

$r \quad$ Reduced

sat Saturated

\section{REFERENCES}

[1] Giraud, F., Rullière, R., Toublanc, C., Clausse, M., \& Bonjour, J. (2015). Experimental evidence of a new regime for boiling of water at subatmospheric pressure. Experimental Thermal and Fluid Science, 60, 45-53.

[2] BAKI Touhami, ARIS Abdelkader, étude expérimentale du transfert de chaleur lors de l'ébullition en vase du R141b, Communication Science \& technologie $\mathrm{N}^{\circ}$ 11. Juillet 2012 COST.

[3] B. Touhami, A. Abdelkader, T. Mohamed, Proposal for a correlation raising the impact of the external diameter of a horizontal tube during pool boiling, Int. J. Therm. Sci. 2014. doi:10.1016 /j.ijthermalsci.2014.05.023.

[4] Baki Touhami, Aris Abdelkader, Guessab Ahmed, Impact du diamètre extérieur d'un tube horizontal lors de l'ébullition en vase, 12ème Congrès de Mécanique 21-24 Avril 2015 - Casablanca (Maroc).

[5] BAKI, T. Etude expérimentale et simulation de l'ébullition à l'extérieur d'un tube horizontal (Doctoral dissertation, Université Mohamed Boudiaf des Sciences et de la Technologie-Mohamed Boudiaf d'Oran).

[6] Baki Touhami (2018). Ebullition à l'Extérieur d'un Tube Horizontal, Comparaison de Corrélations, Congrès National sur les Energies et Matériaux (CNEM), 17-18 Décembre 2018, Nâ̂ma Algeria.

[7] Touhami BAKI, Ebullition à l'extérieur d'un Tube Horizontal à des Pressions sous Atmosphérique, Comparaison de Corrélations, $1^{\text {st }}$ International Symposium on Materials, Energy and Environment January 20-21st; 2020, El Oued, ALGERIA, MEE'2020.

[8] Baki T. Survey on the nucleate pool boiling of hydrogen and its limits. Journal of Mechanical and Energy Engineering, Vol. 4(44), No. 2, 2020, pp. 157-166.

[9] Kruzhilin, G. N. (1947). Free-convection transfer of heat from a horizontal plate and boiling liquid. Doklady AN SSSR (Reports of the USSR Academy of Sciences), 58(8), 1657-1660.

[10] Mc Nelly, M. J. (1953). A correlation of rates of heat transfer to nucleate boiling of liquids. J. Imperial College Chem. Eng. Soc, 7, 1834.

[11] Mostinski, I. L. (1963). Application of the rule of corresponding states for calculation of heat transfer and critical heat flux. Teploenergetika, 4(4), 66-71.

[12] D.A. Labuntsov, Heat transfer problems with nucleate boiling of liquids, Thermal Engineering 19 (9) (1972) 21-28.

[13] Tewari, P. K., Verma, R. K., Ramani, M. P. S., \& Mahajan, S. P. (1985). Studies on nucleate boiling of sodium chloride solutions at atmospheric and sub-atmospheric pressures. Desalination, 52(3), $335-344$

[14] Varma, H. K., Mehrotra, R. K., Agrawal, K. N., \& Singh, S. (1994). Heat transfer during pool boiling of LiBr-water solutions at sub atmospheric pressures. International communications in heat and mass transfer, 21(4), 539-548.

[15] Bhaumik, S., Agarwal, V. K., \& Gupta, S. C. (2004). A generalized correlation of nucleate pool boiling of liquids, Indian journal of chemical technology Vol. 11, pp. 719-725. 
[16] Jabardo, J. M., Silva, E., Ribatski, G., \& de Barros, S. F. (2004). Evaluation of the Rohsenow correlation through experimental pool boiling of halocarbon refrigerants on cylindrical surfaces. Journal of the Brazilian Society of Mechanical Sciences and Engineering, 26(2), 218-230.

[17] Prasad, L., Siraj Alam, M., Gupta, S. C., \& Agarwal, V. K. (2007). Enhanced boiling of methanol on copper coated surface. Chemical Engineering \& Technology: Industrial Chemistry-Plant EquipmentProcess Engineering-Biotechnology, 30(7), 901-906.

[18] Schnabel, L., Scherr, C., \& Weber, C. (2008). Water as refrigerantexperimental evaluation of boiling characteristics at low temperatures and pressures. VII Minsk Int. Semin. "Heat Pipes, Heat Pumps, Refrig. Power Sources, 322-330.

[19] Saiz, J. (2009), Nucleate boiling heat transfer, ECI International Conference on Boiling Heat Transfer Florianópolis-SC-Brazil, 3-7 May 2009.

[20] Chan, M. A., Yap, C. R., \& Ng, K. C. (2010). Pool boiling heat transfer of water on finned surfaces at near vacuum pressures. Journal of heat transfer, 132(3).

[21] Cieśliński, J., \& Kaczmarczyk, T. (2011). The effect of pressure on heat transfer during pool boiling of water-Al2O3 and water- $\mathrm{Cu}$ nanofluids on stainless steel smooth tube. Chemical and Process Engineering, 32(4), 321-332.

[22] Yu, L. H., Xu, S. X., Ma, G. Y., \& Wang, J. (2015). Experimental research on water boiling heat transfer on horizontal copper rod surface at sub-atmospheric pressure. Energies, 8(9), 10141-10152.

[23] Halon, T., Zajaczkowski, B., Krolicki, Z., \& Wojtasik, K. (2015). Calculation and experimental verification of heat transfer coefficient for low pressure methanol evaporator. In ICR 2015 Proceedings: Proceedings of the 24th IIR International Congress of Refrigeration. IIF-IIR Paris.

[24] Tarun Kumar, C. H. Tyagi, Varun Tyagi, 2016, Effect of heat flux and pressure on heat transfer coefficient during the boiling of distilled water and benzene, International Research Journal of Engineering and Technology (IRJET) Volume: 03 Issue: 09 | Sep -2016.
Creative Commons Attribution License 4.0 (Attribution 4.0 International, CC BY 4.0)

This article is published under the terms of the Creative Commons Attribution License 4.0 https://creativecommons.org/licenses/by/4.0/deed.en US 